\title{
Genotoxicity and Histopathological Studies on the Liver, Kidney and Lymphocytes of Male Rats Fed on Diet Containing Waste Fat Released from Chicken During Grilling Process
}

\author{
Hassan $\mathbf{G M}^{1 *}$ and Mazher $\mathrm{KHM}^{2}$ \\ ${ }^{1}$ Genetics Dept., Fac. Agric., Fayoum Univ., Egypt \\ ${ }^{2}$ Cytol. Histol. Dept., Fac. Vet. Med., Beni Suif Univ., Egypt
}

\begin{abstract}
Fat released from chicken during grilling process, as waste, is used by some low income people in Egypt in cooking as dietary fat because it is a cheap fat source compared to other fats. The present study aimed to elucidate the genotoxic and histopatholgic effects of grilled chicken fat on the liver, kidney and lymphocytes of male albino rats. Fifteen two months old male rats were divided to three groups, the first group was fed on control diet, the second and third groups were fed diets containing wasted fat at substitution levels of 50 and $100 \%$ from the fat of diet, respectively. The animals were fed ad-libtium for eight weeks. The single cell gel electrophoresis (Comet) assay is a simple and effective method for detecting DNA damage in control and treated rat cells, and results showed significant increase in tailed nuclei (DNA damage), tail moment , \% DNA in the tail and tail length in liver, kidney and lymphocytes of treated groups compared to the control.In addition, both liver and kidney of treated rats showed a marked degenerative changes congestion of blood vessels in addition to loss of protein, polysaccharides and DNA content.
\end{abstract}

Keywords: Chicken grilled fat; Comet assay; Genotoxicity; Histopathology; Liver; Kidney; Lymphocytes; Rats

\section{Introduction}

Food is an essential factor providing sustenance but may also has a great role in the genesis of human diseases. An association between the intake of grilled or broiled meat and development of cancer was recorded by Thomson et al. [1].Grilling meat, fish or other foods with intense heat over a direct flame result in fat dripping on the hot fire and yielding flames containing a number of polycyclic hydrocarbons (PAHs), such harmful chemicals adhere to the surface of the food. The more intense the heat, the more PAHs is present [2]. PAHs are produced from organic compounds by condensation of smaller units at high temperatures forming stable polynuclear aromatic compounds. At high temperature, organic compounds are easily fragmented into smaller compounds, mostly free radicals, which may then recombine to form a number of relatively stable PAHs [3]. Lin et al. [4] showed that, mice fed high fat diet developed more severe disease and had a shorter life span. Weisburger et al. [5] found that the use of grilled meats in diet, where compounds formed on the surface of meat may be associated with increased risk of genotoxicity and cancer. They also showed that, normal intestinal bacteria can convert one of these compounds, 2-amino-3-methyl-3H-imidazo [2, 5-f] quinolin (IQ) to the 7-hydroxy metabolite, 2-amino-3,6-dihydro-3methyl-7-H-imidazolo(4,5-F) quinolin-7-6(7-OHIQ), a direct acting mutagen. The surface of fried and grilled meat or fish contain powerful mutagens, Sugimura et al. [6] isolated these mutagens and identified them as heterocyclic aromatic compounds with an exocyclic amino group and often an O-methyl group.

The heterocyclic amines formed by partial pyrolysis of amino acids, sugar or creatinine at high temperatures have been shown to be carcinogenic and mutagenic in mice and rats [7]. Food mutagens cause different types of DNA damage, nucleotide alterations and gross chromosomal aberrations. Most mutagens begin their action at the DNA level by forming carcinogen-DNA adducts, which result from the covalent binding of a carcinogen or part of a carcinogen to a nucleotide.
The single cell gel electrophoresis (SCGE) assay, also known as the comet assay, is a rapid, simple, visual and sensitive technique for detecting and analyzing DNA strand breakage in a variety of organs and various mammalian cells [8]. The advantage of the comet assay is that it allows any viable eukaryote cells to be analyzed. For these reasons, the comet assay is now widely used in researches of biomonitoring and DNA damage processes to routine assessments of genotoxicity. Quantitative analysis for DNA damage has yielded several parameters, including tailed nuclei, tail length, \% DNA in the tail, and tail moment in the comet assay [9].

Singh et al. [10] made microgels slides and electrophoresing under alkaline conditions and removed the DNA supercoiling and denaturated the DS DNA to SS DNA. With this modification they obtained a dose response curve with respect to length of DNA migration. The resulting images were subsequently named 'Comet' because of their appearance and their total length was considered directly related to the DNA damage. From that moment a range of applications of the Comet assay have been used in investigations of the physiochemical behavior of DNA, through studies of cellular responses of DNA damage, to biomonitoring of human population.

When the Comet assay technique is used to detect in vivo genotoxicity, the most important advantage is that DNA lesions can be measured in cells not engaged in mitotic activity, making it possible to

*Corresponding author: Hassan GM, Genetics Dept., Fac. Agric., Fayoum Univ., Egypt, Tel: +2-084-6380655; Fax: +2-084-6334964; E-mail: gamalmohamedin@ yahoo.com,gmh01@fayoum.edu.eg

Received December 05, 2010; Accepted February 09, 2011; Published February 11, 2011

Citation: Hassan GM, Mazher KHM (2011) Genotoxicity and Histopathological Studies on the Liver, Kidney and Lymphocytes of Male Rats Fed on Diet Containing Waste Fat Released from Chicken During Grilling Process. J Cytol Histol 2:111. doi:10.4172/2157-7099.1000111

Copyright: ( $) 2011$ Hassan GM, et al. This is an open-access article distributed under the terms of the Creative Commons Attribution License, which permits unrestricted use, distribution, and reproduction in any medium, provided the original author and source are credited. 
Citation: Hassan GM, Mazher KHM (2011) Genotoxicity and Histopathological Studies on the Liver, Kidney and Lymphocytes of Male Rats Fed on Diet Containing Waste Fat Released from Chicken During Grilling Process. J Cytol Histol 2:111. doi:10.4172/2157-7099.1000111

assay many organs [11]. The grilled chicken fat is widely used by low income people in Egypt and other developing countries. Thus the aim of this study was to evaluate the genotoxic and histopathologic effects on liver and kidney of rats fed on diet contained fats of grilled chicken.

\section{Materials and Methods}

\section{Preparation of grilled chicken fat}

About fifteen kilograms from liquids released as waste from chicken during grilling process were collected from different restaurants in Fayoum and Beni-Suef governorates, Egypt. The liquid was held at low temperature $\left(7 \pm 2^{\circ} \mathrm{C}\right)$ for 3 hours for solidification of fat fraction that was then separated from other liquids, the fat portion was rendered by heating and filtered by using cheese cloth for separation of any foreign matters, and then they obtained fat was directly analyzed.

\section{Animals and diets}

Fifteen Swiss male albino rats weighing approximately $90 \pm 10 \mathrm{~g}$ were used. The rats were obtained from the Animal House of the Faculty of Science, Fayoum University, Egypt. Food and water were provided ad-libitum. After feeding on the basal diet for one week as adaptation period, the animals were divided into three groups with five rats in each group. The first group was fed on control diet containing 5\% corn oil; while the second and the third groups were fed diets containing wasted fat as substitution for the diet fat at levels of 50 and $100 \%$, respectively. The experimental diets that contained the grilled fat chicken and corn oil according to AOAC [12].

\section{Genomic DNA isolation from liver and kidney}

The liver and kidney were surgically removed from each rat and instantly immersed in liquid nitrogen and grounded using an autoclaved ceramic pestle. About $17 \mathrm{mg}$ of the grounded tissue was added to $600 \mu \mathrm{l}$ of Nuclei Lysis Solution, according to Surzycki [13]. Genomic DNA was fractioned on agarose gel electrophoresis (1.2\%) and ethidium bromide staining.

\section{Detection of DNA damage by the comet assay}

The portions of the liver and kidney were minced and suspended in chilled homogenizing buffer ( $\mathrm{pH} 7.5) 0.075 \mathrm{M} \mathrm{Nacl}$ and $0.024 \mathrm{M}$ $\mathrm{Na}_{2}$ EDTA, and then homogenized gently using homogenizer in ice. The cells suspension was centrifuged at $4^{\circ} \mathrm{C}, 700 \mathrm{X} \mathrm{g}$ for $10 \mathrm{~min}$. The

cells were re suspended in the cold buffer. [14]. Lymphocytes were isolated by the standard method according to Brulles and Wells [15]. The comet assay was carried out under alkaline conditions, basically as described by Singh et al. [10]. In control and treated rats, digital images were scanned into an image analyzer (Comet analyzer software IV) to determine the length of DNA migration (Comet tail length) due to genotoxicity. Tail length, \% DNA in the tail and tail moment were obtained by observing 25 nuclei for each rat and all assays were performed in triplicate and compared with control. The tail length is the distance from the comet head to the last visible signal in the tail. The percentage of DNA in the tail is calculated from the fraction of DNA in the tail divided by the amount of DNA in the nucleus multiplied by 100 . The tail moment is the product of the amount of DNA in the tail and mean distance of migration in the tail [8].

\section{Histopathological examination}

After eight weeks the animals were sacrificed. The liver and kidneys were excised and fixed in neutral buffered formalin 10\%; the organs were routinely processed and sectioned at 4 to $5 \mathrm{~mm}$ thickness. The obtained tissue sections were collected on glass slides, deparaffinized and stained with Hematoxylin and Eosin stain, bromophenol blue, Feulgen technique and PAS technique [16]. The sections are then examined and observed under light microscope at 400X magnification.

\section{Statistical analysis of data}

Comet sassay data were analyzed for homogeneity of variance using the General linear Model procedure of statistical analysis system (SPSS, 1999). Variable means for treatments indicating significant differences in the ANOVA were compared and, the significances were indicated using Duncan multiple range tests [17].

\section{Results and Discussion}

\section{Electrophoretic pattern of liver and kidney DNA}

A comparison of the gel electrophoretic DNA band patterns in liver and kidney of control and treated rats are shown in Figure 1, as revealed from the figure, the genomic DNA of control group showed definite bands, while the bands of treated groups gave damaged and smear bands. The damage was clear in the liver of treated rats, this may be due to ingestion of genotoxic compounds in the treated diet. Most of genotoxic compounds begin their action at the DNA level causing

\begin{tabular}{|c|c|c|c|c|c|c|c|}
\hline Treatments & & $\begin{array}{l}\text { Head length } \\
\text { (microns) }\end{array}$ & $\begin{array}{l}\text { Tail length } \\
\text { (microns) }\end{array}$ & $\begin{array}{l}\text { Head \% } \\
\text { intensity }\end{array}$ & $\begin{array}{c}\text { Tail \% } \\
\text { intensity }\end{array}$ & $\begin{array}{l}\text { Tail migration } \\
\text { (microns) }\end{array}$ & $\begin{array}{l}\text { Tail moment } \\
\text { (microns) }\end{array}$ \\
\hline Control & \multirow{3}{*}{$\stackrel{\bar{\Phi}}{\stackrel{亠}{\Xi}}$} & $\begin{array}{c}12.98 \pm \\
0.37^{\mathrm{b}}\end{array}$ & $\begin{array}{l}7.62 \pm \\
0.89^{c}\end{array}$ & $\begin{array}{c}90.98 \pm \\
2.76^{\mathrm{A}}\end{array}$ & $\begin{array}{l}7.22 \pm \\
3.16^{\mathrm{B}}\end{array}$ & $\begin{array}{l}1.36 \pm \\
0.61^{\mathrm{C}}\end{array}$ & $\begin{array}{l}0.50 \pm \\
0.24^{\mathrm{C}}\end{array}$ \\
\hline Diet with $2.5 \%$ grilled fat & & $\begin{array}{c}19.04 \pm \\
1.88^{\mathrm{a}}\end{array}$ & $\begin{array}{c}13.86 \pm \\
1.91^{\mathrm{B}}\end{array}$ & $\begin{array}{c}81.97 \pm \\
5.00^{\mathrm{A}}\end{array}$ & $\begin{array}{c}18.02 \pm \\
5.00^{\mathrm{B}}\end{array}$ & $\begin{array}{l}4.34 \pm \\
1.30^{\mathrm{B}}\end{array}$ & $\begin{array}{l}1.68 \pm \\
0.51^{\mathrm{B}}\end{array}$ \\
\hline Diet with $5 \%$ grilled fat & & $\begin{array}{c}16.89 \pm \\
0.95^{\mathrm{a}}\end{array}$ & $\begin{array}{c}18.35 \pm \\
0.99^{A}\end{array}$ & $\begin{array}{c}67.89 \pm \\
2.23^{\mathrm{B}}\end{array}$ & $\begin{array}{c}32.11 \pm \\
2.23^{\mathrm{A}}\end{array}$ & $\begin{array}{c}9.91 \pm \\
0.640^{A}\end{array}$ & $\begin{array}{l}3.50 \pm \\
0.29^{A}\end{array}$ \\
\hline Control & \multirow{3}{*}{ 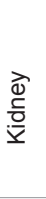 } & $\begin{array}{c}14.74 \pm \\
2.44^{\mathrm{a}}\end{array}$ & $\begin{array}{l}6.44 \pm \\
0.56^{\mathrm{C}}\end{array}$ & $\begin{array}{c}96.29 \pm \\
2.43^{\mathrm{A}}\end{array}$ & $\begin{array}{l}3.71 \pm \\
2.43^{\mathrm{C}}\end{array}$ & $\begin{array}{l}0.24 \pm \\
0.25^{c}\end{array}$ & $\begin{array}{l}0.15 \pm \\
0.10^{c}\end{array}$ \\
\hline Diet with $2.5 \%$ grilled fat & & $13.96 \pm 0.78^{a}$ & $\begin{array}{c}10.25 \pm \\
1.18^{\mathrm{B}}\end{array}$ & $\begin{array}{c}80.37 \pm \\
5.37^{\mathrm{B}}\end{array}$ & $\begin{array}{c}19.63 \pm \\
5.37^{\mathrm{B}}\end{array}$ & $\begin{array}{l}3.27 . \pm \\
1.06^{\mathrm{B}}\end{array}$ & $\begin{array}{l}1.44 \pm \\
0.42^{\mathrm{B}}\end{array}$ \\
\hline Diet with $5 \%$ grilled fat & & $14.34 \pm 0.37^{\mathrm{a}}$ & $\begin{array}{c}15.72 \pm \\
0.92^{\mathrm{A}}\end{array}$ & $\begin{array}{l}66.84 \pm \\
4.53^{c}\end{array}$ & $\begin{array}{c}33.16 \pm \\
4.53^{\mathrm{A}}\end{array}$ & $\begin{array}{l}8.54 \pm \\
0.86^{A}\end{array}$ & $\begin{array}{l}3.08 \pm \\
0.42^{\mathrm{A}}\end{array}$ \\
\hline Control & \multirow{3}{*}{ 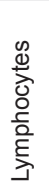 } & $\begin{array}{c}13.37 \pm \\
0.36^{\mathrm{a}}\end{array}$ & $\begin{array}{l}6.74 \pm \\
0.28^{\mathrm{B}}\end{array}$ & $\begin{array}{c}96.30 \pm \\
2.86^{\mathrm{A}}\end{array}$ & $\begin{array}{l}3.70 \pm \\
2.86^{\mathrm{B}}\end{array}$ & $\begin{array}{l}0.39 \pm \\
0.25^{\mathrm{B}}\end{array}$ & $\begin{array}{l}0.22 \pm \\
0.17^{B}\end{array}$ \\
\hline Diet with $2.5 \%$ grilled fat & & $\begin{array}{c}17.08 \pm \\
1.86^{\mathrm{a}}\end{array}$ & $\begin{array}{c}16.00 \pm \\
0.93^{\mathrm{A}}\end{array}$ & $\begin{array}{c}80.98 \pm \\
3.35^{\mathrm{B}}\end{array}$ & $\begin{array}{c}20.28 \pm \\
2.86^{\mathrm{A}}\end{array}$ & $\begin{array}{l}7.45 \pm \\
1.12^{\mathrm{A}}\end{array}$ & $\begin{array}{l}2.12 \pm \\
0.20^{\mathrm{A}}\end{array}$ \\
\hline Diet with $5 \%$ grilled fat & & $\begin{array}{c}13.76 \pm \\
0.79^{a}\end{array}$ & $\begin{array}{c}14.54 \pm \\
0.88^{\mathrm{A}}\end{array}$ & $\begin{array}{c}74.56 \pm \\
3.22^{\mathrm{B}}\end{array}$ & $\begin{array}{c}25.44 \pm \\
3.22^{\mathrm{A}}\end{array}$ & $\begin{array}{l}7.65 \pm \\
1.16^{\mathrm{A}}\end{array}$ & $\begin{array}{l}2.54 \pm \\
0.42^{\mathrm{A}}\end{array}$ \\
\hline
\end{tabular}

Values in the same column within the same item followed by different letters are significantly different $(P>0.05$ for a to $\mathrm{c}$; $\mathrm{P}>0.01$ for $\mathrm{A}$ to $\mathrm{C})$

Table 1: Comet assay parameters obtained by image analysis in cells isolated from liver, kidney and lymphocytes in rats after dministration with diet contained grilled fat. 
Citation: Hassan GM, Mazher KHM (2011) Genotoxicity and Histopathological Studies on the Liver, Kidney and Lymphocytes of Male Rats Fed on Diet Containing Waste Fat Released from Chicken During Grilling Process. J Cytol Histol 2:111. doi:10.4172/2157-7099.1000111

Page 3 of 8

DNA-adducts which bind mutagen to a nucleotide [18]. An increase in DNA damage is indicated by the increase in migration length of the stained DNA.

\section{Comet assay}

The head length, tail length, head \% intensity, tail \%intensity, tail migration and tail moment in the treated and control rats were obtained using automated image analysis software as described in Table 1 . The results in Table 1 and Figure 2, 3 and 4 showed that grilled chicken fat induced a significant concentration-dependent increase in the tail length, tail intensity\%, tail migration and tail moments in the liver, kidneys and lymphocytes respectively. These results suggested that the observed DNA damage was due to genotoxicity and comet assay might be used to detect the DNA damage induced by grilled fat in rat liver, kidneys and lymphocytes. We chose the tail moment to present the results because it facilitates comparison among the tested agents. In the control group, the tail moment was $0.50 \pm 0.24,0.15 \pm 0.10$ and $0.22 \pm 0.17$

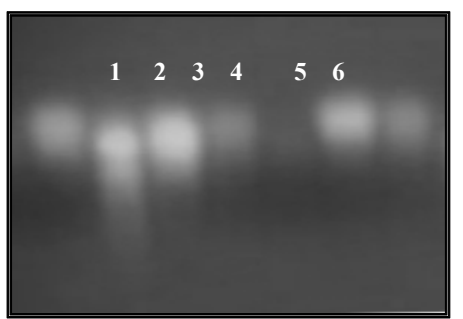

Figure 1: Agarose gel electrophoretic pattern: Liver DNA (1: control); 2: (2.5\% grilled fat); 3: (5\% grilled fat); kidney DNA (4: control); $5:(2.5 \%$ grilled fat) and 6: (5\% grilled fat)
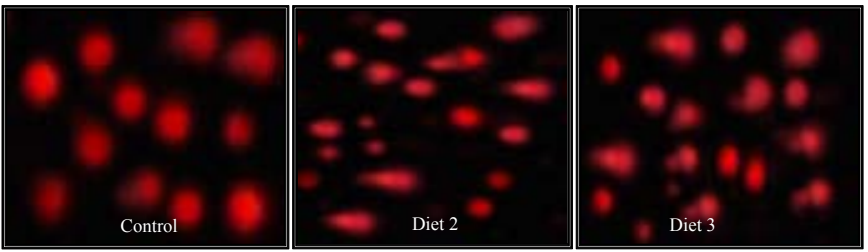

Figure 2: Photomicrographs representative DNA damage (comet assay) in liver of rats fed on control diet and diet containing different concentrations of grilled chicken fat.
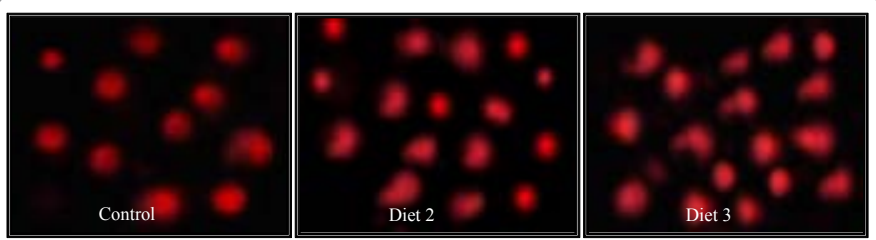

Figure 3: Photomicrographs representative DNA damage (comet assay) in kidney of rats fed on control diet and diet containing different concentrations of grilled chicken fat.
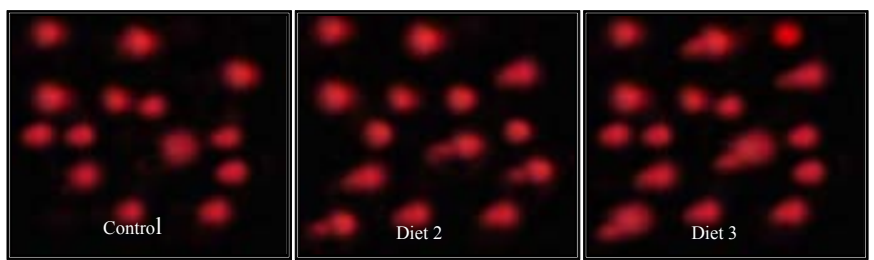

Figure 4: Photomicrographs representative DNA damage (come assay) in lymphocytes, of rats fed on control diet and diet containing different concentrations of grilled chicken fat.

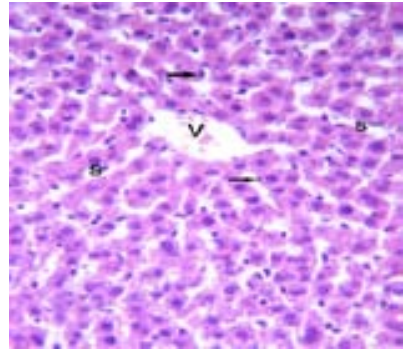

Figure 5: A photomicrograph of the liver of control rats stained with H\&E showing normal hepatic lobule has a thin walled central vein (V), hepatic cords radiating towards the periphery alternating with hepatic sinusoids(S) lined by Kupfer cells and endothelial cells (arrow). X, 400

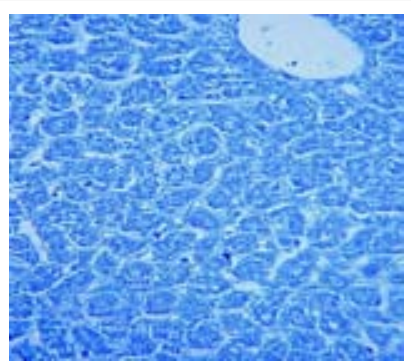

Figure 6: A photomicrograph of the liver of control rats stained with bromopheno showing normal content of total protein in the hepatocytes as indicated by the intense blue stainability. X, 400 .

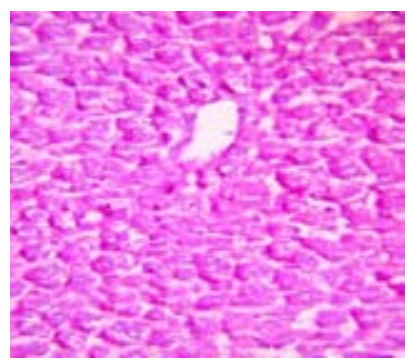

Figure 7: A photomicrograph of the liver of control rats stained with Feulgen technique showing normal content of DNA in the hepatocytes as indicated by the intense magenta colour.X, 400 .

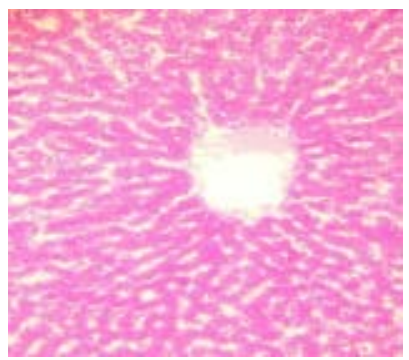

Figure 8: A photomicrograph of the liver of control rats stained with PAS technique showing normal content of general polysaccharides as indicated by the intense red colour. X, 400 .

$\mu \mathrm{m}$ for the liver, kidney and lymphocytes respectively where in the treated groups the tail moment increased in a dose-dependent fashion. When the grilled fat in rats diet was $5 \%$ tail moment of $3.50 \pm 0.29$, $3.08 \pm 0.42$ and $2.54 \pm 0.42 \mu \mathrm{m}$ in the liver, kidney and lymphocytes respectively were observed. Our results suggest that the in vivo comet assay might be used to detect the DNA damage induced by mutagen 
Citation: Hassan GM, Mazher KHM (2011) Genotoxicity and Histopathological Studies on the Liver, Kidney and Lymphocytes of Male Rats Fed on Diet Containing Waste Fat Released from Chicken During Grilling Process. J Cytol Histol 2:111. doi:10.4172/2157-7099.1000111

Page 4 of 8

compounds released during grilled processed foods and the presence of several PAHs in the grilled fat is a measure of the potential for cellular injury through hydroxyl radicals generation. The changes that occurred in liver and kidney DNA may be due to the presence of the PAHs in the grilled fat which increase the free radicals in liver and kidney. The excess of such free radicals combined with some ions resulting in DNA damage [19].

The amount of DNA breakage in a cell in the comet assay was estimated from the migration extent (tail length) of the genetic material in the direction of anode [10]. Furthermore, the percentage of DNA in the tail (tail intensity) has been shown to be proportional to the frequency of DNA strand breaks [8]. Tail moment is a simple descriptor calculated by the computerized image analysis system considering both the migration tail length as well as the fraction of DNA migrated in the tail [20].

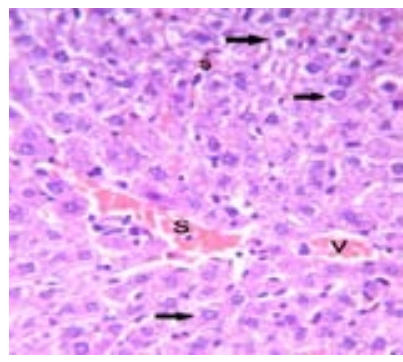

Figure 9: A photomicrograph of the liver of rats feeding with $2.5 \%$ grilled fat stained with H\&E showing dilated and congested central vein $(V)$ and hepatic sinusoids(S). The hepatocytes (arrow) appeared vacuolated and some of them are degenerated. X, 400 .

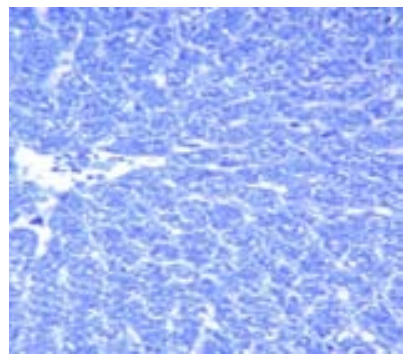

Figure 10: A photomicrograph of the liver of rats feeding with $2.5 \%$ grilled fat stained with bromophenol showing moderate protein contents as indicated by moderate blue stainability. X, 400 .

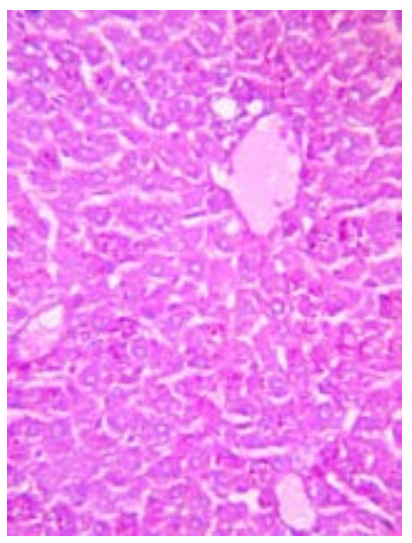

Figure 11: A photomicrograph of the liver of rats feeding with $2.5 \%$ grilled fat stained with Feulgen technique showing reduced content of DNA in the hepatocytes as indicated by the moderate magenta colour.X, 400 .

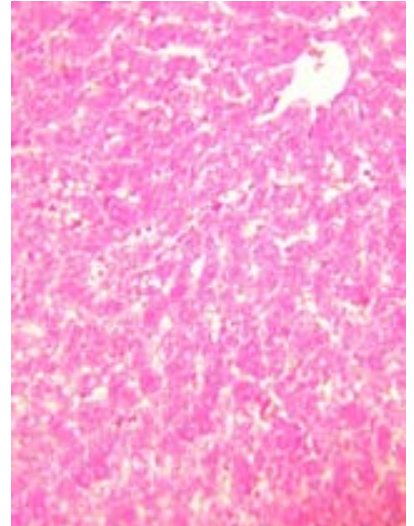

Figure 12: A photomicrograph of the liver of rats feeding with $2.5 \%$ grilled fat stained with PAS technique showing moderate content of general polysaccharides as indicated by the moderate red colour. X, 400 .

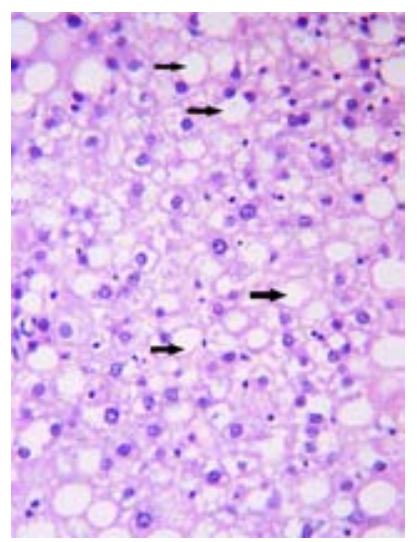

Figure 13: A photomicrograph of the liver of rats feeding with $5 \%$ grilled fat stained with $\mathrm{H} \& \mathrm{E}$ showing that most of hepatocytes are degenerates with marked fatty changes (arrow). Most of the hepatic sinusoids are destroyed. X, 400 .

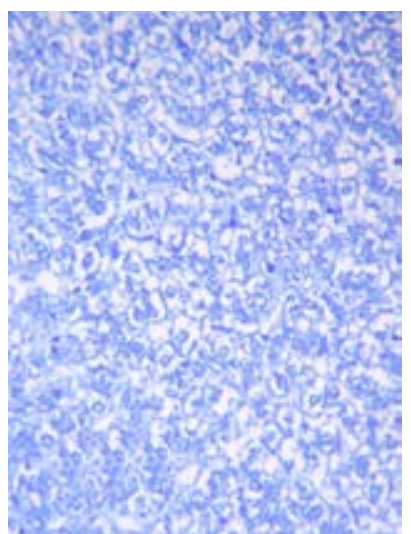

Figure 14: A photomicrograph of the liver of rats feeding with $5 \%$ grilled fat stained with bromophenol showing marked depletion of protein contents as indicated by the weak blue stainability .X, 400 .

\section{Histopathological findings}

The liver: The hepatic parenchyma of the control rats consisted of several hepatic lobules separated from each other by very delicate connective tissue septa housing the portal triad. Each hepatic lobule contained a thin walled central vein surrounded by hepatic cords 
Citation: Hassan GM, Mazher KHM (2011) Genotoxicity and Histopathological Studies on the Liver, Kidney and Lymphocytes of Male Rats Fed on Diet Containing Waste Fat Released from Chicken During Grilling Process. J Cytol Histol 2:111. doi:10.4172/2157-7099.1000111

Page 5 of 8

radiating towards the periphery. The hepatic cords were formed of hepatocytes arranged in cord manner of one or two rows of cells. The hepatic cords were separated from each other by the hepatic sinusoids. The latter appeared wide irregular blood spaces lined by endothelial cells and Von Kupffer cells (Figure 5). Similar findings were mentioned

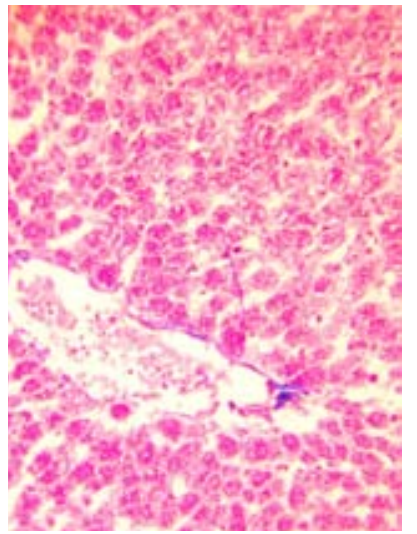

Figure 15: A photomicrograph of the liver of rats feeding with $5 \%$ grilled fat stained with Feulgen technique showing a marked depletion of DNA in the hepatocytes as indicated by the weak magenta colour.X, 400

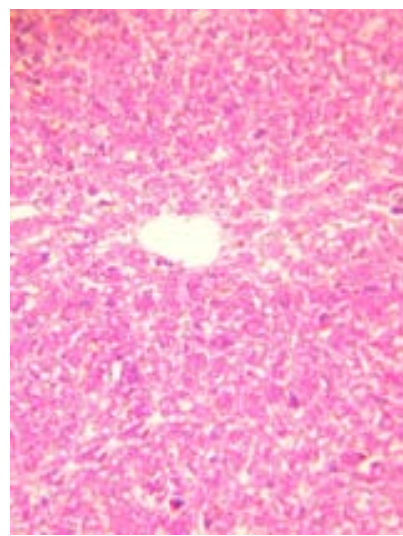

Figure 16: A photomicrograph of the liver of rats feeding with $5 \%$ grilled fat stained with PAS technique showing a marked reduction of general polysaccharides as indicated by the weak to moderate red colour. X, 400

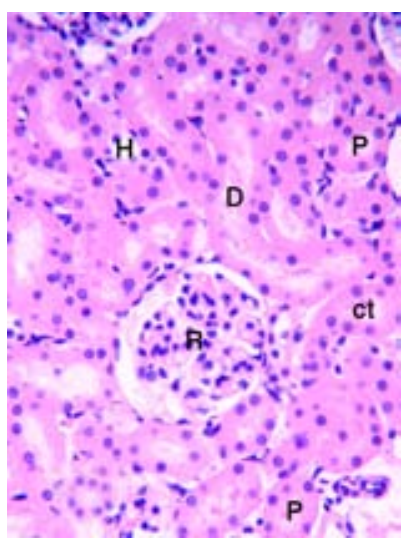

Figure 17: A photomicrograph of the kidney of control rats stained with $\mathrm{H} \& \mathrm{E}$ showing normal histological structure of renal; corpuscle $(R)$, proximal convoluted tubule $(P)$, distal convoluted tubule $(D)$, henles loop $(H)$, and collecting tubule (CT). X, 400

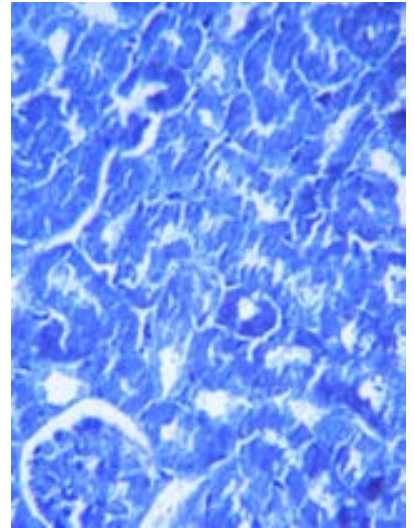

Figure 18: A photomicrograph of the kidney of control rats stained with bromophenol showing normal protein content in the uriniferous tubules as indicated by intense blue stainability. X, 400 .

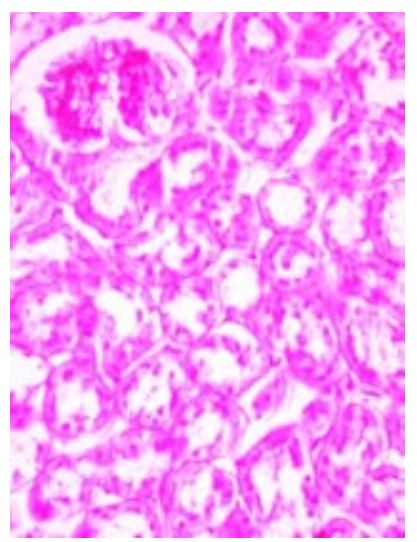

Figure 19: A photomicrograph of the kidney of control rats stained with Feulgen technique showing normal DNA content in the uriniferous tubules as indicated by strong magenta colour.X, 400 .

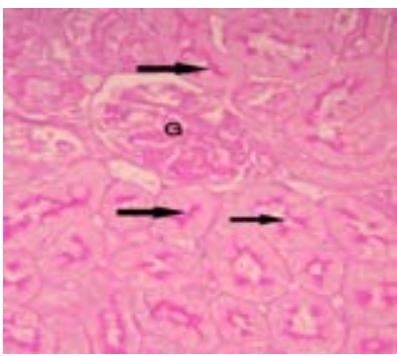

Figure 20: A photomicrograph of the kidney of control rats stained with PAS technique showing strong reaction in the glomeruli $(G)$, brush borders (arrow) and basement membrane (arrow head). X, 400.

by Sharma and Iqbal [21] and Sharma et al. [22]. The hepatocytes appeared polyhedral or hexagonal in shape showing intensive reaction to bromophenol blue indicating high contents of total protein (Figure 6) as stated by Mazia et al. [23] and [24]. The hepatocytes also showed intense magenta colour when treated with Feulgen technique as shown in Figure 7 indicating high amount of DNA material in the nucleus and sometimes the cytoplasm as presented by Feulgen and Rossenbeck [25]. The normal hepatocytes exhibited strong PAS reaction indicating the normal and intense localization of mucopolysaccharides and/or glycogen (Figure 8) as interpreted by Rawat et al. [26].

The rats of the second group showed generalized dilatation and 
Citation: Hassan GM, Mazher KHM (2011) Genotoxicity and Histopathological Studies on the Liver, Kidney and Lymphocytes of Male Rats Fed on Diet Containing Waste Fat Released from Chicken During Grilling Process. J Cytol Histol 2:111. doi:10.4172/2157-7099.1000111

Page 6 of 8

congestion involving the hepatic arteries, lymph vessels, central veins and hepatic sinusoids. The hepatocytes appeared vacuolated ballooned and some of them showed degenerative changes while the nuclei appeared pyknotic and densely stained (Figure 9). The hepatocytes lost some of their total protein which was indicated by the moderate bluish stainability (Figure 10). Also, the DNA content of the hepatocytes especially in the nuclei became greatly decreased as indicated by the moderate magenta colour of Feulgen reaction (Figure 11). Moreover the general polysaccharides in the hepatocytes of this group became reduced to a moderate amount as observed in Figure 12.

In the third group, further degenerative changes in the liver became advanced and progressive resulting in fatty changes and accumulation of variable amount of fat in the hepatocytes while most of the nuclei appeared pyknotic and karyolytic. Also the hepatic sinusoids were

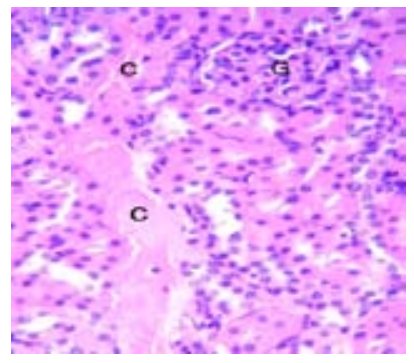

Figure 21: A photomicrograph of the kidney of rats feeding with $2.5 \%$ grilled fat stained with $\mathrm{H} \& \mathrm{E}$ showing degeneration of glomerular tuft $(\mathrm{G})$ and brush borders of renal tubules with accumulation of hyaline cast $(C)$ beside lymphocyteic infiltration. X, 400.

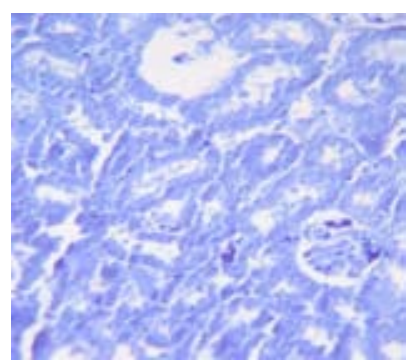

Figure 22: A photomicrograph of the kidney of rats feeding with $2.5 \%$ grilled fat stained with bromophenol showing moderate protein content in the uriniferous tubules as indicated by moderate blue stainability. X, 400 .

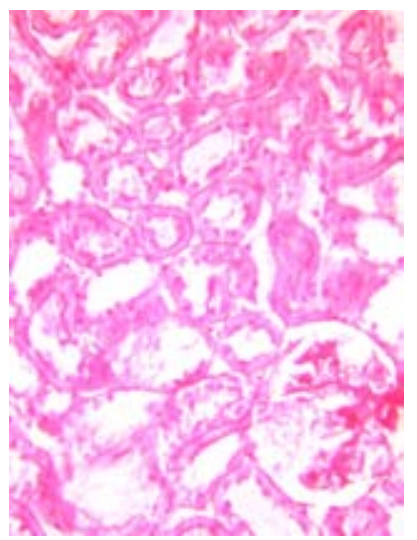

Figure 23: A photomicrograph of the kidney of rats feeding with $2.5 \%$ grilled fat stained with Feulgen technique showing moderate DNA content in the uriniferous tubules as indicated by moderate magenta colour.X, 400

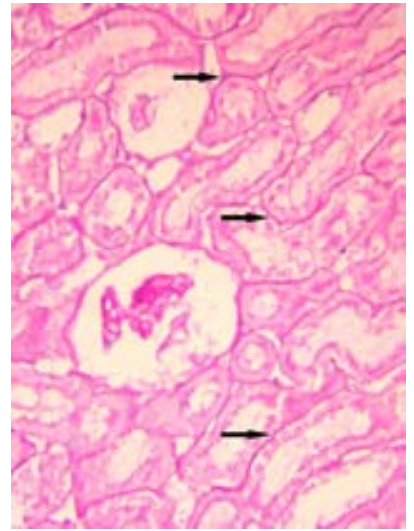

Figure 24: A photomicrograph of the kidney of rats feeding with $2.5 \%$ grilled fat stained with PAS technique showing strong reaction in the basement membrane (arrow) and absent in the brush borders. X, 400.

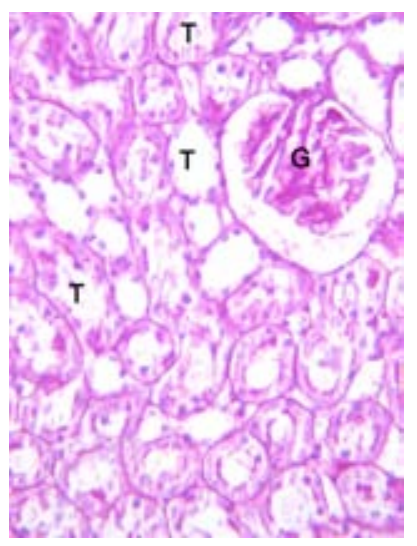

Figure 25: A photomicrograph of the kidney of rats feeding with $5 \%$ grilled fat stained with $\mathrm{H} \& \mathrm{E}$ showing degeneration and hyalinization of glomerular tuft $(G)$ and marked degenerationof the renal tubules (T) .X,400.

markedly degenerated and destroyed (Figure 13). The hepatocytes lost most of their total protein as indicated by faint blue stainabilty (Figure 14).Furthermore, a marked depletion and great reduction of both DNA material and general polysaccharides to their minimal amount was an expected result in this group (Figure 15 and 16). These results are in accordance with [27-30]. Moreover, the polycyclic hydrocarbons PAHs has a direct destructive and degenerative effect on the cellular constituents mainly the chromatin materials resulting in protein depletion, DNA damage and gene destruction [31-34].

The hepatocellular damage is augmented by the elevated liver function tests (GOT \& GPT). Klastskin and Oconn [24] attributed the dilatation and congestion of hepatic vessels and sinusoids to the direct toxic effect of the toxins leading to hepatocellular damage. The authors also reported that lymphocytic infiltration was seen near the central veins. The marked decrease in total protein, DNA material and general polysaccharides is attributed to the hepatocellular damage.

The kidney: The kidney of the control rats showed the normal histological structure of the renal corpuscles and renal tubules. The renal corpuscle consisted of tuft of blood capillaries surrounded by the Bowmann's capsule. The latter has a parietal layer lined by squamous cells and a visceral layer lined by podocytes. The renal tubules included proximal convoluted tubules lined by large pyramidal cells with brush border, distal convoluted tubules lined by cuboidal cells, loop of Henle 
Citation: Hassan GM, Mazher KHM (2011) Genotoxicity and Histopathological Studies on the Liver, Kidney and Lymphocytes of Male Rats Fed on Diet Containing Waste Fat Released from Chicken During Grilling Process. J Cytol Histol 2:111. doi:10.4172/2157-7099.1000111

Page 7 of 8

and collecting tubules (Figure 17). Similar findings were recorded by $[35,36]$. All the cellular components of the renal cortex of normal rats showed the normal contents of the total protein, and DNA material (Figure 18 and 19) as explained by Mazia et al. [23] and Feulgen and Rossenbeck [25]. The general polysaccharides are concentrated in the glomerular tuft, brush borders and basement membranes of the renal tubule (Figure 20) as reported by Selim [36].

The kidney of the second group showed degeneration of the glomerular tuft with infiltration of lymphocytes. The renal tubules became vacuolated and lost their brush borders (Figure 21). The cells of both renal corpuscle and renal tubules lost a considerable amount of total protein and DNA material as indicated by the moderate reaction for both bromophenol blue and Feulgen technique (Figure 22 and 23). In this group the general polysaccharides became greatly decreased in the glomerular tuft and basement membranes while the degenerated brush borders showed negative reaction (Figure 24).

In the third group a progressive degeneration of the glomerular tuft and renal tubules took place (Figure 28). Also focal areas of hyalinization were a marked sign in the group together with loss of cellular architecture (Figure 25). Moreover, the affected cells lost the majority of their cytoplasmic protein as indicated by the faint blue colour (Figure 26). Also the DNA content was reduced to a minimum degree as explained by weak magenta colour (Figure 27). These results

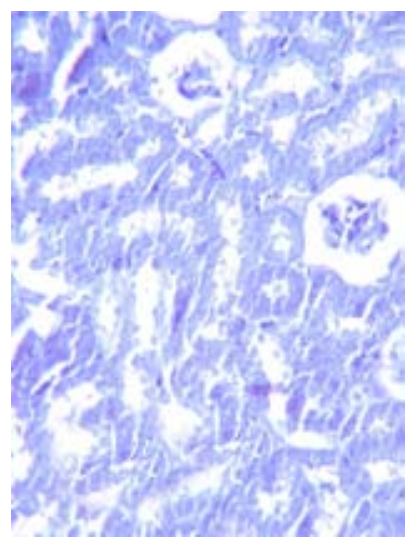

Figure 26: A photomicrograph of the kidney of rats feeding with $5 \%$ grilled fat stained with bromophenol showing a marked reduction of protein content in the uriniferous tubules as indicated by faint blue stainability. X, 400 .

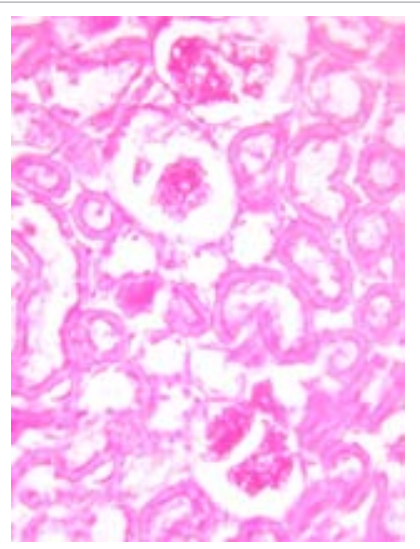

Figure 27: A photomicrograph of the kidney of rats feeding with $5 \%$ grilled fat stained with Feulgen technique showing minimal DNA content in the uriniferous tubules as indicated by faint magenta colour.X, 400 .

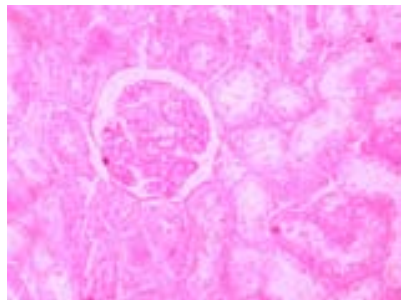

Figure 28: A photomicrograph of the kidney of rats feeding with $5 \%$ grilled fat stained with PAS technique showing strong reaction in the basement membrane and absent in the brush borders. X, 400 .

are in accordance with $[35,37,38]$. The degenerative changes recorded in the kidney of the treated rats are augmented by the elevated kidney function tests as creatinine and urea. The loss of cellular protein may be due to disorganization of the rough endoplasmic reticulum that lacks the full complement of ribosomes [39,40]. Sasaki et al. [41] stated that the food additives as well as fatty diet induced DNA damage. The depletion of polysaccharide is attributed to the damage of the renal tissue and brush borders [24].

The degenerative changes observed in the present study would indicate the local action of the grilled fat on both liver and kidney as they considered the main sites of detoxification and excretion of toxic materials of administered substances [30-34].

\section{References}

1. Thomson BM, Lake R J, Cressey PJ, Knize MG (1996) Estimated cance risk from heterocyclic amines in cooked meat a New Zealand perspective. Proceedings of the Nutrition Society 21.

2. Larsson BK (1986) Polycyclic aromatic hydrocarbons in Swedish foods Aspects on analysis, occurrence and intake. Doctoral thesis, Swedish University Sciences.

3. Lijinsky W (1991) The formation and occurrence of polynuclear aromatic hydrocarbons associated with food. Mutat Res 259: 251-261.

4. Lin BF, Huang CC, Chiang BL, Jeng SJ (1996) Dietary fat influences la antigen expression, cytokine and prostaglandin E2 production of immune cells in autoimmune - prone NZB x NZW F1 mice. Br J Nutr 75: 711-722.

5. Weisburger JH, Rivenson A, Kingston DG, Wilkins TD, Nagao M, et al. (1995) Dietary modulation of the carcinogenicity of the heterocyclic amines, In Heterocyclic amins in cooked foods: Possible human carcinogens, Princeton scientific Adamson, R. H.; Gustafsson, J. A.; Ito, N., Nagao,T.; Sugimura,T.; Yamazoe,Y. (Eds.) publishing Co., Inc, Princeton, NJ, p. 240-250.

6. Sugimura T, Nagao M, Kawachi T, Honda M, Yahagi T, et al. (1977) Mutagencarcinogens in foods, with special reference to highly mutagenic pyrolytic products in broiled foods. In: Origins of Human Cancer. Hiatt, H. H., Watson, J.D. and Winsten, J. A. (Eds) Cold Spring Harbor Laboratory, Cold Spring Harbor, New York, NY, p. 1561-1577.

7. Ohgaki H, Takayama S, Sugimuro T (1991) Carcinogenicities of heterocyclic amines in cooked food. Mutat Res 259: 399-410.

8. Olive PL, Banath JP, Durand RE (1990) Detection of etoposide resistance by measuringDNA damage in individual Chinese hamster cells. J Natl Cancer Inst 82: 779-783.

9. Tice RR, Agurell E, Anderson D, Burlinson B, Hartmann A, et al. (2000) Single cell gel/Comet Assay: guidelines for in vitro and in vivo genetic toxicology testing. Environ Mol Mutagen 35: 206-221.

10. Singh NP, MyCoy MT, Tice RR, Schneider EL (1988) A simple technique for quantification of low levels of DNA damage in individual cells. Exp Cel Res 175: $184-191$.

11. Fairbairn DW, Olive PL, O'Neill KL (1995) The comet assay: a comprehensive review. Mutat Res 339: 37-59.

12. AOAC (1990) Official method of analysis (15 ed.) Association of off officia analytical chemisits, Virginia, DC. 
Citation: Hassan GM, Mazher KHM (2011) Genotoxicity and Histopathological Studies on the Liver, Kidney and Lymphocytes of Male Rats Fed on Diet Containing Waste Fat Released from Chicken During Grilling Process. J Cytol Histol 2:111. doi:10.4172/2157-7099.1000111

13. Surzycki S (2000) In. Basic techniques in molecular biology preparation of genomic DNA from animal cells. Springer-verlag publications, BerlinHeidelborg., 40-44.

14. Sasaki YF, Tsuda S, Izumiyama F, Nishidate E (1997) Detection of chemically induced DNA lesions in multiple mouse organs (liver, lung, spleen, kidney, and bone marrow) using the alkaline single cell gel electrophoresis (Comet) assay. Mutat Res 388: 33-44.

15. Brulles S, Wells PW (1977) In vitro stimulation of avian lymphocytes by various mutagens. Research Veterinary Science 23: 84-86.

16. Bancroft JD, Gamble M (2002) Theory and practice of histological techniques. In: Microorganisms, B. Swisher, (Editor), Churchill. Livingstone, Philadelphia, $325-344$

17. Duncan DB (1955) Multiple range and Multiple F tests. Biometrics 11: 1-42.

18. Goldman R, Shields PG (2003) Food mutagens. Journal of Nutration 133: 965973.

19. Guidarelli A, Cattabeni F, Cantoni O (1997) Alternative mechanisms for hydroperoxide-induced DNA single strand breakage. Free Radic Res 26: 537 547.

20. Villarini M, Moretti M, Pasquini R, Scassellati-Sforzolini G, Fatigoni C, et al (1998) In vitro genotoxic effects of the insecticide deltamethrin in human peripheral blood leucocytes: DNA damage ('comet' assay) in relation to the induction of sister chromatid exchanges and micronuclei. Toxicology 130: 129139

21. Sharma SD, Iqbal M (2005) Lithium induced toxicity in rats: a hematological biochemical and histopathological study. Biol Pharm Bull 28: 834-837.

22. Sharma S, Goyal RP, Chakravarty G, Sharma A (2008) Toxicity of tomato red, a popular food dye blend on male albino mice. Exp Toxicol Pathol 60: 51-57.

23. Mazia D, Brewer PA, Alfert M (1953) The cytochemical staining and measurement of protein with mercuric bromophenol blue. Biological Bulletin 104: 57-67.

24. Klastskin G, Oconn H (1993) Abnormalities of the hepatic parenchyma. In Histopathology of liver . Vol. 1. Oxford Uni. Press, New York, p. 40-55.

25. Feulgen R., Rossenbeck H (1924) Mikroskopisch nach weis einen nucleinsaure von typus thymonucleinsaure und de darauf berhende elective farbug von zelkernen in microskopischen preparaten. Zeitschrift Physiology Chemistry 135: 203.

26. Rawat DK, Bais VS, Agrawal NC (2002) A correlative study on liver glycogen and endosulfan toxicity in Heteropes fossilis (Bloch.). J Environ Biol 23: 205207.

27. Aly KA (1997) Physiological and histopathological effects of some synthetic food colouring additives in rats. PhD. Thesis, Faculty of Science, Cairo University.
28. El-Shamy KA, Khadr ME, Morsy FA, Hassanin MM (1999) Toxic effects of some food additives of albino rat, green colours. Egyptian Journal of Zoology 32 417-440.

29. Kaboglu A, Actac T (2002) A study of the effects of sodium benzoate on the mouse liver. Biologia Bratislava 57: 373-380.

30. Hussein TD, Amer MA, Hamza AS, Samir I (2007) Effect of erythrosine on the liver of albino mice. Egyptian Journal of Zoology 49: 1-21.

31. Xue X, Xiao Y, Zhu H, Wang H, Liu Y, et al. (2008) Induction of P450 1A by 3methylcholanthrene protects mice from aristolochic acid-l-induced acute renal injury. Nephrol Dial Transplant 23: 3074-3081.

32. Maître A, Lefèbvre E, Marques M, Rajhi A, Douki T, et al. (2011) Polycyclic aromatic hydrocarbons in binary mixtures modulate the efficiency of benzo[a] pyrene to form DNA adducts in human cells. Toxicology 11: 36-44.

33. Nukaya M, Walisser JA, Moran SM, Kennedy GD, Bradfield CA (2010) Ary hydrocarbon receptor nuclear translocator in hepatocytes is required for aryl hydrocarbon receptor-mediated adaptive and toxic responses in liver. Toxicol Sci 118: 554-563.

34. Bunger MK, Glover E, Moran SM, Walisser JA, Lahvis GP, et al. (2008) Abnormal liver development and resistance to 2,3,7,8-tetrachlorodibenzo-pdioxin toxicity in mice carrying a mutation in the DNA-binding domain of the ary hydrocarbon receptor. Toxicol Sci 106: 83-92.

35. Ford SM, Hook JB, Bond JT (1980) The effect of butylated hydroxyanisole and butylated hydroxytoluene on renal function in the rat. I. Effects on fluid and electrolyte excretion. Food Cosmet Toxicol 18: 15-20.

36. Selim ME (2005) Monosodium glutamate-induced nephrotoxicity on young mice and the possible counteracting effect of barley. Egyptian Journal of Zoology 45: 101-121.

37. Oslen P, Meyer O, Bille N, Wurtyen G (1986) Carcinogenicity study on BHT in Wistar rat exposed in utero. Food Chem Toxicol 24: 1-12

38. Attia ZI, Basyuni MA, Hegazi MA, Okba SG (2005) Effects of benzene sulfonic acid the physiology and growth rate of young rats. Egyptian Journal of Zoology 45: 373-387.

39. Early JL 2nd, Novainakere VK, Weaver A (1992) Effect of cadmium on live mitochondria and rough endoplasmic reticulum in the rat. Toxicol Lett 62: 73-83.

40. Tsuda S, Murakami M, Matsusaka N, Kano K, Taniguchi K, et al. (2001) DNA damage induced by red food dyes orally administered to pregnant and male mice. Toxicol Sci 61: 92-99.

41. Sasaki YF, Kawaguchi S, Kamaya A, Ohshita M, Kabasawav K, et al (2002) The comet assay with 8 mouse organs: results with 39 currently used food additives. Mutat Res 519: 103-119. 